\title{
Economic Reforms and an African Market Economy
}

\author{
Oluremi Ogun \\ University of Ibadan, Ibadan, Nigeria \\ Email: 1rogun@gmail.com
}

How to cite this paper: Ogun, O. (2018) Economic Reforms and an African Market Economy. Open Access Library Journal, 5: e4242.

https://doi.org/10.4236/oalib.1104242

Received: December 11, 2017

Accepted: January 12, 2018

Published: January 15, 2018

Copyright (c) 2018 by author and Open Access Library Inc.

This work is licensed under the Creative

Commons Attribution International

License (CC BY 4.0).

http://creativecommons.org/licenses/by/4.0/

\section{(c) (i) Open Access}

\begin{abstract}
Economic reforms described the collection of policies to re-orientate economic activities in an attempt to re-direct the desired course of evolution of an economy. They were therefore aimed at altering the structure of an economic system for sustainable growth. Economic reforms in Nigeria had their genesis in the structural adjustment program instituted in 1986 to stem the tide of dwindling economic fortunes consequent upon the glut in the market for the country's main export resource as well as the management oversight of the oil-boom era. Economic regulation had been the general management philosophy in the period before and during the oil boom of the 1970s. Several other reform programs had succeeded the 1986 initiatives. Mostly, the reforms were directed at eliminating distortions in the various markets and relying on market forces for resource allocation and general macroeconomic decisions. Based on a descriptive analytical method, this study showed that the expectations of a smaller government size and a larger private sector were realized. Also, the remarkable expansion in the telecommunications and the education sectors were gains. A combination of low technical changes and little innovations appeared to explain the dwindling contributions of other activity sectors and the general inert economy.
\end{abstract}

\section{Subject Areas}

Macroeconomics

\section{Keywords}

Industry Studies-Manufacturing, Services, Telecommunications, Agriculture, Economy-Wide Country Studies-Africa, Innovation and Invention

\section{Introduction}

A country undertook economic reforms mostly when it had experienced pro- 
longed period of sluggish growth. The reform could be of short term duration usually to correct the anomalies or eliminate distortions in sectors known to be the sources of the slow growth. On the other hand, it could be comprehensively long term going beyond short term sectoral adjustment but also attending to issues of structural nature that may be impinging on production patterns as well as innovation matters to relieve the problem of slow technical change. Usually, the long term reforms were implemented in stages for error correction between phases.

Since its political independence in 1960, Nigeria had experienced its worst growth performance in the early to the mid-1980s that succeeded the first oil boom period of 1973-'80. Real growth in the period had averaged about -3.1 per cent. It had been an average of about 4.2 per cent in the oil boom period (about 27 per cent average in nominal terms). It had even been higher at about 6 per cent average in the 1960s. The severe recession came on the heels of an enormous fiscal response to the boom. Hence, the country was left with an asymmetric growth structure with declining export revenue, growing import bills and relatively larger and expanding untradable goods' sector. Accordingly, accumulated trade payment arrears caused the external debt of the country to grow at an unprecedented rate of about 76 per cent per annum. By 1985, the external debt of the country had climbed to about US $\$ 19.4$ billion to constitute about 39 per cent and 154 per cent of the country's GDP and exports respectively; it even grew more rapidly to about US $\$ 33$ billion by 1987 . The need for policy adjustment to alter the production and consumption patterns of the country became rather very obvious.

Attempts were made in 1982 to tackle the situation using control measures such as quantitative restrictions and exchange control. As these actions were influenced by the assumption that the problem was temporary, they became mere palliatives that escalated the problem through various sectors with the cumulated results indicated in the preceding paragraph. In essence, the declining oil export revenue translated directly to declining real growth and serious unemployment.

The first major comprehensive attempt at reforming the economy began in the fourth quarter of 1986 when the foreign exchange market was deregulated. The deregulation of the banking sector soon followed and by 1988 when the policy components of the adjustment program unfolded, an interim tariff and excise tax system characterized by unprecedented low levels of rates had been put in place; the design of the tariff rates' was aimed at achieving uniformity by 1994. Several incentives for export promotion were introduced while subsidies to government owned enterprises were curtailed. The initial adjustment efforts were to be carried forward and sustained through a three-year economic consolidation and expansion program, several rolling plans, economic blue prints, policies on rule of law and equity, and public sector downsizing program.

Overall success ratings had been mixed calling forth an evaluation of the poli- 
cies, programs and outcomes of the reforms in the country. The rest of the paper was organized as follows. Section 2 provided an insight into the theoretical basis of economic reforms while the section following presented an overview of the contents of the policies and programs implemented under the Nigerian reform process. Section 4 dealt with the outcomes while, the last section gave a concluding remark.

\section{Framework of Analysis}

At the initial phase of an economic reform, three broad categories of policies were evident-demand based, supply based and trade based. These could be further decomposed into four categories-demand management policies, exchange rate and production policies, structural policies and external financing policies. Demand management policies that were aimed at restraining aggregate demand and absorption were absolutely necessary during the early stages of a reform process. Exchange rate policy had expenditure switching effect on both the tradable and untradable goods while production incentive policy boost production and growth in the newly favored tradable goods' sector. External financing policies aimed at improving the supply of foreign funds and the management of external debt. ${ }^{1}$

The particular policies emphasized would be informed by the situation of a country. For countries where all of the above standard components of reforms were already in place, the reform effort might take the form of relieving structural rigidity by way of innovation policies through a restructuring of the national systems of innovation.

The impetus for economic reforms as implemented around the world took root from neo-classical economics which assumed that a country's economy should be open, with a competitive market; firms were expected to earn a profit without any external subsidy or protection. The World Bank (WB) and International Monetary Fund (IMF) relying on the neo-classical economic theory advocated that governments in developing and transition economies should cut subsidies, liberalize prices, and privatize State Owned Enterprises (SOE).

Much of the economic theorizing behind the demand management component of a reform process was traceable to the analytical model developed by [1]. The model could be explained using four sectors as fundamental structure of an economy: the private sector, government sector, foreign sector and domestic banking sector (which consisted of only the Central Bank). These sectors constituted the aggregate national accounts. The general principle was that, the value of production in the economy equals the value of incomes generated, or, in other words, income from production in each sector plus net transfers must equal expenditures plus savings. When the four accounts were totaled, the result was the national income identity: ${ }^{2}$

${ }^{1}$ These designs were motivated by the Bretton Wood institutions as subsequently discussed in the paper. ${ }^{2}$ For details on the four accounts constituting the core of a country's system of national accounts, see [1]. 


$$
Y=(C+I)+X-Z
$$

where $Y$ was national income (at market prices), $C$, was combined consumption of government and private sectors, $I$ was investment of both sectors, and $X$ and $Z$ were exports and imports respectively. $C+I$ indicated the amount of goods and services absorbed in the economy and came from domestic production $(Y)$ and the net balance of the external sector. The four macro accounts helped to identify the relevant variables at play in a country's macroeconomic framework and were also helpful tools in the discussion of the issues involved in structural adjustment program. Their usefulness was illustrated by the two examples below.

Using the national balance equation and rewriting gives:

$$
X-Z=Y-(C+I)
$$

The equation showed that if the trade balance $(X-Z)$ turned negative (e.g. reflecting an external shock such as a fall in the international terms of trade), this shock and the associated trade balance deficit must be adjusted either by a rise in $Y$ or a decrease in absorption $(C+I)$. As it was far more difficult to increase African production levels $(Y)$ in the short term, policy measures initially focused on reducing absorption $(C+I)$, that is, aggregate demand in the economy. This demand-side stabilization was usually brought about by a combination of fiscal and monetary policies, largely within the domain of IMF activities.

An important question here was whether to make cuts primarily in consumption $(C)$ or in investments $(I)$. Unfortunately in practice in African terms, cuts in investments were often preferred and the politically far more sensitive consumption aggregate was usually left largely unaltered. The equation clearly showed that the necessary lowering of demand (belt-tightening) could be limited if $Y$ (production level) could be simultaneously increased ${ }^{3}$. The required supply-side measures (largely the responsibility of WB) aimed to enhance growth in national production (including exports) and focused on policies that made resources work more efficiently and/or create additional production capacity in the economy.

Another example of how these macro identities could be helpful in identifying relevant policy issues involved the government budget balance. There was good reason to focus on the government (or public) sector as it was widely believed that rapid increases in government fiscal deficits in African countries should be considered an important source of macroeconomic imbalance. It followed that the approach to successful stabilization necessitated a reduced fiscal deficit. Referring to Equation (3) in the macroeconomic accounts of the model in [1], the government budget restraint was presented as:

$$
S_{g}-I_{g}=\Delta N F A_{g}-\Delta N P B_{g}-\Delta D C_{g}
$$

where, $S_{g}$ was government savings, $I_{g}$ was investment spending of government, ${ }^{3}$ Criticisms of the reform design could be found in [2]. 
$N F A_{g}$ was net foreign asset as controlled or owned by the government, $N P B_{g}$ was government borrowing from the private sector and DC was domestic credit to the government from the monetary sector.

It was clear from the equation that a fiscal deficit $\left(S_{g}-I_{g}=\right.$ negative $)$ could be financed in three ways: first, by running down NFA (foreign assets) through decreasing international reserves; second, by increasing NPB (attracting loans from the private sector), and finally by augmenting credit drawn from the monetary sector $(\triangle D C)$. If no additional loans from either the external or domestic private sector were available, which was often the case in Sub-Saharan Africa, the determining factor of the fiscal deficit would be the third actor in the play namely, domestic credit from the central bank. If this policy instrument was used to establish a ceiling for domestic credit (a favorite IMF policy priority), then African governments were forced to redress their fiscal deficit by directly increasing revenues (through higher fees for their public services) or decreasing the expenditures ([3] p. 46).

This sector-based macroeconomic framework thus provided a useful tool for identifying variables subjected to stabilization and adjustment policies; however, the equations used were all identities meaning that they were by definition all in balance ex post. Hence, this framework of accounts did not provide information about how the macro-variables were linked to each other or, in other words, what the causal interplay between variables was and how the adjustment process to a new equilibrium actually took place. It should also be remembered that an accounting framework implicitly assumed a linear, fixed-coefficient economy, implying that neither phenomena such as productivity growth and changes in the institutional setting nor substitution possibilities could be incorporated into the framework ([3] p. 55). In order to develop a theory, one needed to explore the behavioral relationships between the macro-aggregates and subsequently formulate hypotheses.

\section{The Nigerian Reform Process}

This was organized under two major headings as follows.

\subsection{The Background}

The reform process in Nigeria could be segmented into two phases: the military governments' inspired processes and the civilian governments' initiatives. Although some laudable measures were introduced and notable institutions established during the military era, the general poor economic management of the period created several gaps in the reform agenda and further need for new initiatives. Thus, the background to economic reforms in the country could be summarized thus: prolonged period of economic stagnation; rising poverty levels leading to deteriorating and incomparable human development vis-à-vis other less developed countries; widespread corruption; public investments' deficits resulting into severe infrastructural bottlenecks that hindered private sector activities. 
Concomitantly, there was high level macroeconomic volatility driven largely by external terms of trade and the country's over reliance on oil export earnings: reference [4] ranked the country as the most volatile in the world for the period 1960 to 2000. Government expenditure closely followed current revenues, implying that fluctuations in oil earnings were transferred directly into the domestic economy. Fluctuations in public expenditure reflected both the over-reliance on oil earnings and weak fiscal discipline by previous governments. Volatile fiscal spending also tended to cause real exchange rate volatility. In particular, fiscal expansions financed by oil revenues often resulted in domestic currency appreciation, creating "Dutch-disease" concerns and reducing competitiveness of the non-oil economy [5].

There were two other consequences of the volatile state of government expenditure. Firstly, expenditure volatility resulted in low quality government public spending, often with many incomplete capital projects, as well as the accrual of arrears for civil servant salaries and government contractor payments. Indeed, by 2003 , accumulated arrears to domestic contractors alone amounted to about N150 billion (US $\$ 1.17$ billion at that time). Secondly, macroeconomic instability also hindered long-term planning by the private sector and resulted in a concentration of economic activity in various short-term arbitrage opportunities (particularly in retail trade) rather than productive long-term investments. Overall, a procyclical expenditure pattern coupled with poor management of oil earnings resulted in low growth, persistent fiscal deficits, and the accumulation of debts.

Moreover, the public sector was underperforming and imposed a significant financial drain on the Treasury. Within the sector, the inefficiency and underperformance of SOEs were particularly costly: for example, in 2001, direct government financial support to SOEs represented about 0.68 per cent of GDP (about US\$323 million). Besides, reference [6] estimated that for the period 2000 to 2003 , it costed the federal government about $\$ 74.3$ billion (US $\$ 558$ million) to operate the Nigerian Ports Authority in direct financial flows and various foregone earnings to the government.

In addition, the civil service was oversized, poorly remunerated and lacked requisite technical skills resulting in weak work ethics and poor service delivery. For example, about 70 per cent of workers in the Ministry of Finance were low-level staff clerks, cleaners and administrative staff with secondary school education or equivalent, 13 per cent were university graduates and only 8 per cent had degrees in economics, finance or accounting. More broadly, the government estimated that about 70 per cent of federal civil servants had a high school diploma or lower, with less than 5 per cent possessing modern computer skills. Besides, civil servants generally received low pay and several fringe benefits such as free housing, free vehicles, and various other allowances that often led to waste and misuse of government resources. Weak management and oversight also meant that there were problems with ghost workers on government's payroll, while personnel and pension registers often were unreliable. 
Furthermore, as a result of regulations of the past and the poorly managed liberalization of the SAP era, the banking system was weak and fragmented often financing short term arbitrage opportunities (especially, foreign exchange "round tripping" activities) rather than productive private sector investments. An official inquiry into the causes of the problem in 2008 revealed both exogenous and endogenous factors at work. Notable among the identified causes were: large and sudden withdrawal of foreign capital in 2007; failures of corporate governance; lack of investor and consumer sophistication; inadequate disclosure and transparency about true financial position of several banks; critical gaps in the regulatory framework and regulations; uneven supervision and enforcement; unstructured governance and management processes at the Central bank and weakness in the overall business environment.

With respect to the external sector, the country's trade regime was for the two decades prior to economic reform described as complex, restrictive and opaque [7]. The tariff reforms under SAP that introduced uniform tariff rates became distorted by revisions occasioned by pressures from lobbies. And, at a general level, the country's institutions and governance were generally weak and ineffective as a result of deep-seated rent-seeking and corruption which had accompanied the advent of the oil boom of the 1970s. In a corrupt environment, resources for human capital development and other necessary investments e.g. infrastructure, were diverted. Poor household were disproportionately hurt in communities where corruption was most prevalent.

Analytical studies on the extent of corruption in Nigeria before the recent reforms were often very negative. A survey of Nigerian firms in 2002 revealed widespread bribery across various public institutions. About 70 per cent of firms surveyed reported the need for bribes to obtain trade permits, about 83 per cent paid bribes to obtain utility services, about 65 per cent paid bribes when paying taxes, an estimated 90 per cent paid bribes during procurement, and 70 per cent of firms acknowledged the need for bribes to obtain favorable judicial decisions. In addition, there was widespread perception of leakage of public funds [8]. Moreover, 100 per cent of Nigerian firms surveyed agreed that public funds were diverted to private groups in contrast to about 78 per cent of firms in Russia, and about 45 per cent of firms in South Africa. Finally, a federal government survey noted that prior to 1999 , the government lost an average of about $\$ 40$ billion (US\$300 million) each year to corrupt practices in public procurement. This occurred in various forms: inflation of contract costs, award of contracts for non-existent projects, over invoicing, diversion of public funds to foreign banks, and low project quality because of the use of inexperienced contractors. Moreover, procurement costs in Nigeria were significantly higher compared with costs for similar projects in a neighboring country, Ghana.

\subsection{Reform Measures}

The measures were discussed according to the blocks recognized by the policy design. 


\subsection{Macroeconomic Stability}

The objectives of macroeconomic reform were: 1) to stabilize the Nigerian economy; 2) improve budgetary planning and execution, and 3) provide a platform for sustained economic diversification and non-oil growth. The policy thrust of the reform was to de-link public expenditures from oil revenue earnings by introducing an appropriate fiscal rule. As it was practiced in other countries, the adoption of such a rule could enable the accumulation of government savings, whether for precautionary reasons, for smoothening public expenditures, or for ensuring intergenerational equity [5]. An oil price-based fiscal dependence rule was introduced in which government expenditure was subjected to a prudent oil price benchmark. Any revenues that accumulated above the reference prices were saved in a special excess crude account. In recent years, government budgeting had been based on conservative oil prices of $\$ 25$ per barrel in 2004, $\$ 30$ per barrel in 2005, and $\$ 35$ per barrel in 2006, despite higher realized prices of $\$ 38.3$ and $\$ 54.2$ in 2004 and 2005, respectively, and an estimated average price of $\$ 68$ for 2006 . The adoption of this rule had ensured that government expenditures were de-linked from oil revenue earnings, thereby limiting the transmission of external shocks into the domestic economy.

\subsection{Public Sector Downsizing}

The main instruments of policy were privatization of SOEs and deregulation of government activities in some sectors that were expected to improve efficiency of the enterprises, curb corruption and reduce the financial burden on the Federal government. Between 1999 and 2006, about 116 enterprises were privatized, including various loss-making government enterprises operating in industries such as aluminum, telecommunications, petrochemical, insurance, and hotel. A major component of the privatization program was the unbundling of the Power Holding Company of Nigeria (PHCN) into 18 companies responsible for power generation, transmission, and distribution. In some instances, state owned enterprises such as ports were also concessioned to private sector operators. More recently, the government concluded the successful sale of 51 per cent of its stake in the Hilton Hotel and the sale of the state-owned Nigeria Telecommunications Limited (NITEL). Privatization had also been accompanied by deregulation of various economic sectors to encourage private sector participation, notably in telecommunications, power, and downstream petroleum sectors.

\subsection{Civil Service Reform}

Civil service reform began with five pilot ministries and subsequently extended to nine MDAs (ministries, departments and agencies). In each instance, internal consultations were made while verification exercises were conducted to update personnel records and payroll data. Organizational structures for the reforming ministries were reviewed and rationalized, while the appropriate professional skills needed were identified. Redundancy packages and retraining programs 
were offered to severed staff. A total of 35,700 officials had been severed from the civil service at an estimated cost of about 26 billion (US $\$ 203$ million), while 1000 university graduates were recruited. In the process of restructuring, an estimated 8000 ghost workers were expunged from the payroll.

Government pay scales were reviewed. An initial recommendation from a review committee had suggested public sector wage increases of 25 per cent in 2007 and a further 10 per cent annually (plus cost-of-living adjustment) for the next 10 years. Full implementation of the proposal was likely to result in significant growth of the payroll component of the federal government's budget: the wage bill would have accounted for 35 per cent, 45 per cent and 45 per cent of the national budget in 2007, 2008 and 2009, respectively. The federal government consequently opted to increase wages by 15 per cent from January 2007, with further upward revisions defined by further implementation of the public service reforms. Various public sector benefits such as housing and cars were also monetized and consolidated with basic salaries. Only four non-regular allowances remained: job-specific allowance (e.g. for medical doctors on call), risk-allied allowance (e.g. for employees in risk-prone areas), relocation allowances (e.g. for employees posted abroad), and scarce skills allowance (e.g. for information technology specialists). Finally, government payroll systems were computerized with the introduction of an Integrated Personnel and Payroll Information System (IPPIS) to assist in monitoring staffing numbers in the federal civil service.

\subsection{Banking Sector Reform}

Though the deregulation reforms in Nigeria started in the fourth quarter of 1986 with the foreign exchange market, the reforms pertaining to the banking industry proper did not commence until January 1987. The first reform in the sector was the deregulation of rate of interest on loans and deposits. Thus, competition on price basis among banks was enabled. The interest rate deregulation was soon followed by a policy of free entry into the banking system. The immediate response of the system to these two policies was a surge in the number of banksfrom 56 (Merchant and Commercial banks) in 1986 to 109 by 1990 and 120 by 1992.

Meanwhile, the modus operandi in the hitherto deregulated foreign exchange (FOREX) market was constantly fine-tuned in order to improve market efficiency and minimize sharp practices on the part of dealers (mostly, banks). Accordingly, the initial two windows-official (for government imports and official transactions at administratively determined rates), and non-official (where licensed dealers bid to produce a market determined rate in order to satisfy their clients' request) were merged to constitute only one window called the foreign exchange market (FEM). Further, in order to absorb the parallel foreign exchange market into the official market and cater for the needs of small users of FOREX, government in 1988 granted licenses for bureau de change operations. 
Concurrent with the bureau de change initiative was the introduction of a policy of a mini-universal banking system by which banks were not only permitted to take up equity stakes in non-financial enterprises but could also engage in insurance brokerage. Mindful of the risks inherent in widespread deregulation policy, the Nigerian authorities introduced a new capital base of 1 billion for each category of banks, raising it to 2 billion by the year 2002. By July 2004, the Central bank announced a new capital base of 25 billion for the banks. These stabilization efforts were complemented by the establishment of a deposit insurer in 1988; the corporation was expected to ensure financial stability and provide a healthy platform for the economy.

Other notable money market reforms can be summarized as follows. Interest payment on demand deposit accounts with banks was introduced in 1994; cash reserve ratio was reactivated to work as an indirect instrument of credit control; the use of foreign exchange held in foreign deposit accounts as collateral for loans was prohibited; all government deposits held by commercial and merchant banks were withdrawn so banks could function without undue government interference. In 1993, the Open Market Operations as an indirect instrument of monetary control was introduced. Subsequently, discount houses emerged to intermediate between the Central bank and the other banks, essentially off-loading government treasury securities from the Central bank (warehousing them as necessary) and auctioning same to the banks. In order to ensure that the banks have sufficient capital to absorb shocks in times of operational losses, and also be sure that shareholders in banks have sufficient stake in the system to do a comprehensive oversight job of bank management, the capital adequacy ratio of banks was adjusted from 1.12 to 1.10 .

The policy on capital adequacy ratio was actually part of the prudential guidelines of 1990. The guidelines which were in line with the recommendations of the Basel Committee on Banking Supervision directed banks to make adequate provisions for bad and doubtful debt; to stop accruing interest on non-performing loans, while any past interest accruals should be discountenanced and not recognized as income. The capital adequacy component of the guidelines consisted of a risk weighted measure recognizing five risk-weights: 0 per cent, 10 per cent, 20 per cent, 50 per cent and 100 per cent. Banks were expected to maintain capital funds of at least 7.26 per cent of total risk weighted assets and ensure that at least 50 per cent of their capitals were core or primary (that is, equity plus reserves). The first round of increase in the equity capital of banks in 1990 (from ¥20 to N50 for commercial banks and $\$ 12$ to $\$ 40$ for merchant banks) was in the spirit of the guidelines. Also in the period 1989/90, some special purpose institutions were introduced; these included the People's bank, Community banks and Urban Development bank. Stabilization securities were reintroduced for purposes of monetary and financial control as these securities which were non-transferable and non-negotiable carried higher yield than treasury bills.

In order to strengthen the regulatory and supervisory authorities in the man- 
agement of the reforms, two new decrees were put in place in 1991. The first was the Central Bank of Nigeria (CBN) Decree 24 and the Banks and Other Financial Institutions Decree 25. These decrees respectively empowered the CBN to issue banking licenses and to revoke them, and, to apply any type of measure to handle ailing financial system. By 1991, some of the reform measures of 1987 were reversed, a cap was placed on interest rates standing at 21 per cent for lending rates and 13.5 per cent for deposit rates. Also a maximum interest rate spread was specified (4 per cent). And, in line with the new private sector-driven development and privatization, government in 1992 divested itself from the seven banks where it had 60 per cent equity holding. It was believed that fully private-sector owned banks would be more efficiently managed and hence more effective in its operations and had improved performance.

There were reforms in the capital market too and these included the freeing of stock prices from administrative determination by the Securities and Exchange Commission (SEC). By 1997, additional capital market reforms (e.g. shortening of settlement period to three days) were introduced, while by 1999 , fully-foreign owned banks were given licenses to operate. By the year 2000, foreign currency deposits had become institutionalized while in 2001, government went the whole hog and introduced universal banking, such that a bank could be a complete financial supermarket for its customer.

\subsection{Trade Policy Reforms}

Nigeria liberalized its import tariff regime by adopting the Common External Tariff (CET) of the Economic Community of West African States (ECOWAS). This was in keeping with the government's commitment to simplify the tariff structure and improve the transparency and predictability of Nigeria's trade policies [9]. Under the new ECOWAS tariff structure, Nigeria adopted a four-band arrangement with duty rates of $0,5,10$, and 20 per cent for capital goods, raw materials, intermediate products, and finished goods, respectively. A temporary 50 per cent band existed but was to be phased out by the end of 2007 , while a few import prohibitions would be eliminated progressively. The use of the 50 per cent tariff band was permitted under current ECOWAS trade rules and provided the country with some flexibility in its future industrial policies. For example, the 50 per cent tariff was levied on goods in selected sectors in which the country had comparative advantage and aimed to support domestic production, such as vegetable oils and starch.

Overall, with the adoption of the ECOWAS CET, the simple (unweighted) average tariff rate declined from 29 to 18 per cent, while the weighted average tariff rate fell from 25 to 17 per cent. The CET had also simplified and improved the transparency of Nigeria's tariff structure. Generally, the focus of trade policy reforms had been export promotion through competitiveness of local industries. Besides the tariff reviews, several incentives were introduced to boost export production. As described in the Export and Miscellaneous Provision Decree No. 
18 of 1986, they included, export expansion grant, duty waivers and duty draw-back.

\subsection{Institutional Reforms}

Public procurement: Following an extensive review of public procurement systems, the government introduced a Value for Money audit or Due Process Mechanism (DPM) in public contracts. The DPM had promoted an open tenders process with competitive bidding for government contracts. Any projects exceeding $\$ 50$ million (US\$400,000) also required approval (i.e. a due process certification). To ensure competitive costing of contracts, a database of international prices was developed to serve as a guide during the bidding process. The government also published a public tender's journal periodically as a means of reducing patronage in the award of contracts. Finally, certification of completed government projects was also required before final payments could be made.

Public expenditure management: Poor public expenditure management in Nigeria greatly hampered the quality of government capital projects, resulting in poor service delivery to citizens. Oversight of public expenditures was further made difficult due to existing fiscal decentralization that allocated about half of total government revenues to states and local governments, with the remainder going to the federal government. While increased resource allocation to states and local governments might potentially encourage more direct interventions in pro-poor programs, capacity constraints and the lack of transparency at the subnational level posed serious challenges. To improve transparency at all levels of government, but particularly the sub-national level, a monthly publication of federal, state, and local governments' shares of revenue from the country's federation account was introduced in January 2004. The publication provided details of revenue allocations to all 36 state governments and the Federal Capital Territory (FCT), as well as 774 local governments.

The oil and gas sector and the N-EITI initiative: The lack of transparency in the Nigerian oil and gas sector, particularly under previous military administrations, also presented a major challenge for economic governance. In 2003, Nigeria was among the first countries to adopt the Extractive Industries Transparency Initiative (EITI) to help improve governance of the sector. One of the key acts of the EITI aimed at improving transparency was to commission an independent audit of the oil and gas sector from 1999 to 2004. This was an unprecedented exercise domestically, and Nigeria was the first country in the EITI initiative to commit to such an undertaking. The audit presented a number of instructive findings. Overall, 99.8 per cent of revenues in the sector were accounted for. The balance (that is, 0.02) per cent was within the conventional margin of error for such audits. However, the audit showed a history of poor record keeping. In the financial audit, only minor disparities were observed between revenues that oil companies reported as paid and the actual amounts received by the Central bank.

Coordination among government agencies was however found to be weak and 
government record keeping was also poor such that reported revenues fluctuated: in some years, reported income exceeded what the Central bank received while in others, the reverse was the case. A physical audit also pointed to the systematic loss of crude oil between the wellhead and export metering terminals. Poor metering infrastructure also hampered proper data collection on gross volumes. Finally, the audit highlighted some concerns with the discretionary powers of the petroleum minister in oil block allocation arising from the Petroleum Act of 1969. The findings of the study were subsequently disseminated to the public while various remediation measures were implemented by the government.

Prosecuting corrupt practices: The government introduced two institutions to tackle corruption in the domestic business environment. The Economic and Financial Crimes Commission (EFCC) and the Independent Corrupt Practices and other Related Offences Commission (ICPC) were pursuing cases of corrupt practices such as Internet fraud and corruption in public office. There had been a number of high profile convictions: many advance fee fraud kingpins had been detained, two judges had been sacked and two others suspended, several legislators (including a past Senate president) had lost their legislative posts and were being prosecuted, three ministers had been dismissed, a former Inspector General of Police-the top law enforcement official in the country-had been tried, convicted and jailed for corruption, and three former state governors had been impeached by their state assemblies on account of corruption.

EFCC investigations had made good use of the monthly revenue share publications mentioned earlier, highlighting the importance of information and transparency in the fight against corruption. EFCC and ICPC activities were gradually removing the concept of the untouchable "big man" in the country while re-establishing the rule of law for all. Overall, despite existing challenges, recent governance reforms appeared to have yielded some concrete results. Recent survey data from [8] indicated that there had been a reduction in the perception of corruption by Nigerian firms in obtaining trade permits, in paying taxes, in procurement, in the judiciary, in the leakage of public funds, and in money laundering.

\section{Results}

These were examined at two levels: direct and indirect effects. The direct effect was seen in terms of impact on the instruments while the indirect effect concerned sectoral performances and overall GDP growth.

\subsection{Direct Effects}

The relevant issues under this were as follows.

\subsubsection{Macroeconomic Stability}

There was a marked improvement in government's fiscal balance, with the previous deficit of 3.5 per cent of GDP in 2003 turning into consolidated surpluses 
of about 10 per cent in 2004 and 11 per cent in 2005 [10]. Adoption of the fiscal rule also resulted in significant public savings for the government. Gross excess crude savings totaled about $\$ 6.4$ billion at the end of 2004 and about $\$ 17.7$ billion by the end of 2005. Over the period 2003 to 2006, foreign reserves increased by more than fivefold, from $\$ 7.5$ billion at the end of 2003 to about $\$ 38$ billion in July 2006. The implementation of monetary policy was similarly fairly disciplined, with the Central bank adhering to various monetary targets and reducing inflation. End-year inflation declined from 21.8 per cent in 2003 to 10 per cent in 2004 but increased slightly to 11.6 per cent at the end of 2005. Similarly, interest rates were gradually declining: prime lending rates have declined from about 21.3 per cent at the end of 1999 to 17.6 per cent at the end of 2005 . Finally, the adoption of the Wholesale Dutch Auction System facilitated the convergence of foreign exchange markets and the elimination of a previous parallel market premium.

The improved implementations of fiscal and monetary policies had provided a stable macroeconomic environment that was crowding in private sector participation in the domestic economy. As an example, in 2005, credit to the private sector grew by 30.8 per cent to 2.01 trillion (US\$15.1 billion), exceeding the target growth rate of 22.5 per cent. In addition, net credit to the federal government declined by 37 per cent to $\$ 306$ billion (US $\$ 2.3$ billion) compared with the target decline of 10.9 per cent.

Overall, the attainment of macroeconomic stability provided a platform for improved growth performance in recent years. Growth rates had averaged about 7.1 per cent annually for the period 2003 to 2006 . This was a notable improvement on performance over the pre-reform decade when annual growth rates averaged about $2.3 \%$. More importantly, recent growth surges had been driven by strong growth in the non-oil sectors averaging $4.4,7.4$, and 8.26 per cent successively in 2003, 2004 and 2005.

Progress in oil revenue management and implementation of monetary policy was complemented by improvements in debt management and the budget preparation process. Public debt declined substantially from about 74.8 per cent of GDP in 2003 to about 14.2 per cent in 2006, largely because of a successful debt relief agreement with the Paris Club. In 2004, Nigeria's stock of debt amounted to about $\$ 46.6$ billion, comprised of $\$ 35.9$ billion of external debt and $\$ 10.7$ billion of domestic debt. High debt servicing costs on Nigeria’s $\$ 30.4$ billion Paris Club debt had placed a significant strain on government fiscal resources, crowding out space for other necessary social expenditure and investments in public infrastructure.

Consequent upon the debt negotiations with the Paris Club, Nigeria paid its outstanding arrears of $\$ 6.4$ billion, received a debt write-off of $\$ 16$ billion on the remaining debt stock, and purchased its outstanding $\$ 8$ billion debt under a buyback agreement at 25 per cent discount for $\$ 6$ billion. The entire debt relief package totaled $\$ 18$ billion, or a 60 per cent write-off in return for a $\$ 12.4$ billion 
payment of arrears and buyback. The exercise involving the buyback was unprecedented in the Paris Club for a low-income country and was the second largest debt relief operation in the club's 50-year history. Other external debt, particularly debts owed to London Club of commercial creditors, were similarly restructured and paid off. Payment or restructuring of domestic debt, totaling about 12 per cent of GDP in 2005, presented a bigger challenge. Following an audit of domestic debt arrears, the government took a pragmatic position by capitalizing such arrears through issuance of three-to five-year bonds at competitive interest rates. For contractor arrears, cash payments of about N4.6 billion (US\$36 million) were made while an estimated $\$ 87.6$ billion (US\$684 million) was issued in bonds. Similarly, civil service pension arrears were addressed with cash payments of about $\$ 8.6$ billion (US\$67 million) and about N75 billion (US\$586 million) in bonds [11] [12].

\subsubsection{Public Sector Downsizing}

Between 1989 and 1994, a total of 58 SOEs were sold to the private sector generating an income of about US $\$ 763$ million. The second phase in the privatization exercise was in the 2000-2008 period when 100 SOEs were affected with sales revenue of about US $\$ 6481$ million. The most recent sale under the program was the electricity companies generating about US $\$ 3.3$ billion, thus, bringing the total proceeds from the exercise to about US $\$ 8.5$ billion.

The liberalization of the telecommunication sector was particularly successful, resulting in an increase in the number of telephone lines in the country from about 500,000 landlines in 2001 to over 32 million GSM lines in 2014. The sector attracted over US $\$ 1$ billion a year in investments between 2010 and 2014 and the country had been rated as one of those with the fastest growing teledensity in the world. The privatization and liberalization exercises had been controversial in part and fraught with a great deal of resistance from entrenched interests who were accustomed to diverting public resources for private gain. Though there were questions about the privatization of particular public enterprises (such as whether the process was fair and transparent, or whether private monopolies were being created), most of these issues had been settled and the exercise had been largely successful.

\subsubsection{Financial Sector}

Financial prices had been generally market determined and reflecting both endogenous and exogenous developments. Accordingly, there had been reduced tendency towards misalignment of the prices. Macroeconomic growth and stability as well as external trade and finance had been the ultimate beneficiaries.

\subsubsection{Institutional and Governance Reforms}

With the introduction of the DPM, there was noticeable improvement in the efficiency of capital spending. The federal government had saved over $\$ 200$ billion (about US $\$ 1.5$ billion) since 2001 in the form of reductions in inflated contract prices. Further, initial prices quoted by various government contractors had also 
declined significantly. The DPM which was one of the most hated and resisted in the comprehensive reform package, had also been one of the most successful, bringing more sanity, transparency, and competition into a previously opaque area.

With the coming on stream of EFCC and ICPC, there had been a number of high profile convictions. Overall, about 350 EFCC cases were at an advanced stage of prosecution. About 5,000 people had been arrested over the past three years. There had been about 91 convictions for various corruption crimes and assets worth over $\$ 5$ billion had been seized, confiscated and refunded to the state and the victims of crime.

\subsection{Indirect Effects}

Table 1 presented comparative statistics on the growth performances of four key sectors of the economy that appeared to have experienced the most notable changes under the reform process. In the pre-reform period, manufacturing grew the fastest followed successively by services, agriculture and telecommunications. However, in the post-reform period of 1986-2010, telecommunications was clearly the leading growth activity sector followed at a distance by agriculture, services and manufacturing respectively. In the recent rebased sectoral growth performances, telecommunications' contribution to the GDP in the period 2001-2014 was put at about 8.7 percent $^{4}$.

The relative performances of these sectors were further underscored by their contributions to real GDP in the periods under consideration. Table 2 provided the relevant statistics.

As could be deduced from the Table, the average contribution (in real terms) of the telecommunications sector over the two periods improved by about 167 per cent compared with successive declines of about 8,29 and 13 per cents of agriculture manufacturing and services.

The peculiar performance of the telecommunications sector in the post reform period might not be unconnected with the huge investments in the sector. Between 2001 and 2014, investments in the sector totaled about $\$ 32$ billion and at an annual average growth rate of about 30 per cent. Concomitantly, its labor force grew by an unprecedented 1,549 per cent. The introduction of mobile telephone technologies in the country (buoyed by a large absorptive capacity)

Table 1. Average growth rates of selected sectors (\%).

\begin{tabular}{cccccc}
\hline Period & Telecommunications & Agriculture & Manufacturing & Services & $\begin{array}{c}\text { Total } \\
\text { Nominal GDP }\end{array}$ \\
\hline $1960-1985$ & 12.6 & 13.8 & 21.8 & 18.1 & 17.0 \\
$1986-2010$ & 79.6 & 28.1 & 22.2 & 25.7 & 29.7 \\
\hline
\end{tabular}

Source: Computed from Central Bank of Nigeria, Statistical Bulletin, 2010 (Abuja).

${ }^{4}$ See http://www.theguardan.com/ "Nigeria Becomes Africa's Largest Economy—Get the Data", citing National Bureau of Statistics. 
Table 2. Average contributions of sectors to real gross domestic product.

\begin{tabular}{ccccc}
\hline Period & Telecommunications & Agriculture & Manufacturing & Services \\
\hline $1960-1985$ & 0.03 & 0.40 & 0.07 & 0.15 \\
$1986-2010$ & 0.08 & 0.37 & 0.05 & 0.13 \\
\hline
\end{tabular}

Source: Same as Table 1.

might explain these unusual performance records. As at April 2014, the country had about 129 million active telephone subscribers, up, from the 50 million of the pre-reform era. Teledensity in the country stood at about 92 per cent as against the 0.4 per cent of the pre-reform period. ${ }^{5}$ As at 2014 , there were five active mobile phone companies operating in the country. Of this number, three had multinational links.

Apart from telecommunications, another activity sector that recorded remarkable growth in the post-reform period was education. While policy liberalization stimulated rapid growth in the establishment of educational institutions at all levels, the developments in the tertiary segment were quite remarkable. In 1989 , there were only 28 universities in the country consisting of 20 Federal institutions and the rest, states' owned. By the year 2010, the number of universities had risen to 104 with 27 Federal, 36 states and 41 private. It is interesting to note that before 1986, there was only one private university in the country. Both local and foreign capital were actively engaged in the sector especially at the secondary and tertiary levels.

It appeared that a major incentive for the apparent huge private investments in the educational sector was the high demand for education at all levels in the country. For example, in terms of absorption of applicants into universities, only 1988 ( 22 per cent) and 1989 (28 per cent) figures were above 20 per cent between 1979 and 2010. Whereas, the proportion was as low as 2 per cent in 2008, the number of applicants was as huge as about 1.15 million in $2009 .^{6}$

A sharp contrast to the story of telecommunications was the case of the manufacturing sector. As shown in Table 1 and Table 2, both of its growth and contributions declined significantly over the two relevant periods. Some activities in the sector (e.g. textile) became marked by near-extinction. Textile was the leading export subsector in the country before and in the immediate periods after the initial reforms (that is, between 1986 and 1994). A combination of unfavorable politico-economic developments between 1994 and 1999 and the stiff competition from imported fabrics of the reform era appeared to explain the adverse development in the sector. Generally, the supply response (low technical progress) of the sector under the liberalization process had been very poor.

A slightly different explanation could be proffered for the somewhat slow

\footnotetext{
${ }^{5}$ All information and data relating to the telecommunications sector were from the Nigerian Communications Commission, the National Bureau of Statistics and the International Telecommunications Union.

${ }^{6}$ Figures quoted in respect of university education were from the Joint Admission and Matriculation Board and the National Universities Commission.
} 
Table 3. Distribution and growth of real gross domestic product in selected years (\%).

\begin{tabular}{cccccccc}
\hline Activity & 1980 & 1985 & 1990 & 1995 & 2000 & 2005 & 2010 \\
\hline Agriculture & 20.6 & 32.7 & 31.5 & 34.9 & 35.8 & 41.2 & 41.8 \\
Manufacturing & 11.0 & 6.0 & 5.5 & 4.9 & 4.2 & 3.8 & 4.3 \\
Oil \& Mining & 23.6 & 36.3 & 37.7 & 33.5 & 32.7 & 24.5 & 14.8 \\
Wholesale and & 20.0 & 13.9 & 13.4 & 14.0 & 13.1 & 13.8 & 19.0 \\
Retail Trade & & & & & & & \\
$\begin{array}{c}\text { Building and } \\
\text { Construction }\end{array}$ & 9.7 & 1.6 & 1.6 & 1.9 & 2.0 & 1.5 & 2.0 \\
Infrastructure & 4.3 & 3.7 & 2.6 & 2.8 & 2.8 & 7.7 & 10.2 \\
Services & 10.7 & 5.7 & 7.7 & 8.7 & 9.3 & 7.5 & 7.9 \\
Total & 99.9 & 99.9 & 100.0 & 100.0 & 99.9 & 100.0 & 100.0 \\
Overall GDP & 5.3 & 9.5 & 13.0 & 2.2 & 5.4 & 6.5 & 5.6 \\
Growth Rate & & & & & & & \\
\hline
\end{tabular}

Note: Total of all sectors' growth rates may reflect the effect of rounding; Source: Same as Table 1.

recovery of the agricultural sector from the penalty imposed by the "Dutch disease" incidence of the oil boom and post oil boom era. Peasant farming characterized by small-holdings and the use of simple implements such as hoe and cutlass remained the general practice. Hence, its contribution to real GDP did not quite match up with its status as the residual occupation sector of the economy.

In terms of overall impact, Table 3 presented data on the performance of the major sectors of the economy as well as the general GDP growth in real terms.

As could be seen, agriculture appeared to be the only sector with consistent (though sluggish) improvement in the post reform period. Apart from 1990 that might have benefitted from the oil windfall of the year, overall GDP real growth hardly matched up with the pre-reform (1985) level. In a sense, this might suggest the continuing existence of some form of structural rigidity that could have been limiting the response of the different sectors under the reform process.

\section{Concluding Observation}

The Nigerian reform process had been quite extensive addressing the perceived growth inhibiting problems in every sector of the economy. The output responses of the different sectors varied with remarkable real growth recorded in only the telecommunications sector that appeared to have been propelled by the introduction of new technologies. Indeed, the slow supply responses of the other sectors appeared to be unconnected with little technical changes in the production and service delivery processes. This clearly calls for policy attention to ascertain the causes of the slow innovations and effect redress. Thus, future studies on this subject should be directed at investigating the sources of sectoral innovations. 


\section{References}

[1] Polak, J.J. (1957) Monetary Analysis of Income Formation and Payments Problems. IMF Staff Papers, 6, 1-50. https://doi.org/10.2307/3866128

[2] ECOWAS (1990) Structural Adjustment in West Africa: Achievements, Problems and Prospective. Memorandum to the Joint Meeting of ECOWAS Officials of Planning and Finance, Abuja.

[3] Tarp, F. (1993) Stabilization and Structural Adjustment: Macroeconomic Framework for Analyzing the Crisis in Sub-Saharan Africa. Routledge, US \& Canada. https://doi.org/10.4324/9780203309285

[4] World Bank (2003) Nigeria: Policy Options for Growth and Stability. Report No. 26215-NGA. The World Bank, Washington DC.

[5] Barnett, S. and Ossowski, R. (2002) Operational Aspects of Fiscal Policy in Oil-Producing Countries. Working Paper No. WP/02/177, International Monetary Fund, Washington DC.

[6] Adam Smith International (2006) Analyzing Financial Flows between FGN and Public Enterprises. Economic Policy Position Paper No. 4, Published as Part of the Support to the Bureau of Public Enterprises.

[7] World Trade Organization (2005) Trade Policy Review of Nigeria. World Trade Organization, Geneva.

[8] Kaufmann, D. and Colleagues (2005) Nigeria in Numbers-The Governance Dimension: A Preliminary and Brief Review of Recent Trends on Governance and Corruption. Presentation for the President of Nigeria and His Economic Management Team, Mimeo.

[9] National Planning Commission (2004) The National Economic Empowerment and Development Strategy. National Planning Commission, Abuja.

[10] International Monetary Fund (2005) Nigeria: Request for a Two-Year Policy Support Instrument. International Monetary Fund, Washington DC.

[11] International Monetary Fund (2001) Nigeria: 2001 Article IV Consultation. IMF Country Report No. 01/131, International Monetary Fund, Washington DC.

[12] International Monetary Fund (2003) Nigeria; Staff Report for the 2002 Article IV Consultation. IMF Country Report No. 03/3, International Monetary Fund, Washington DC. 